УДК: 338.432 .5

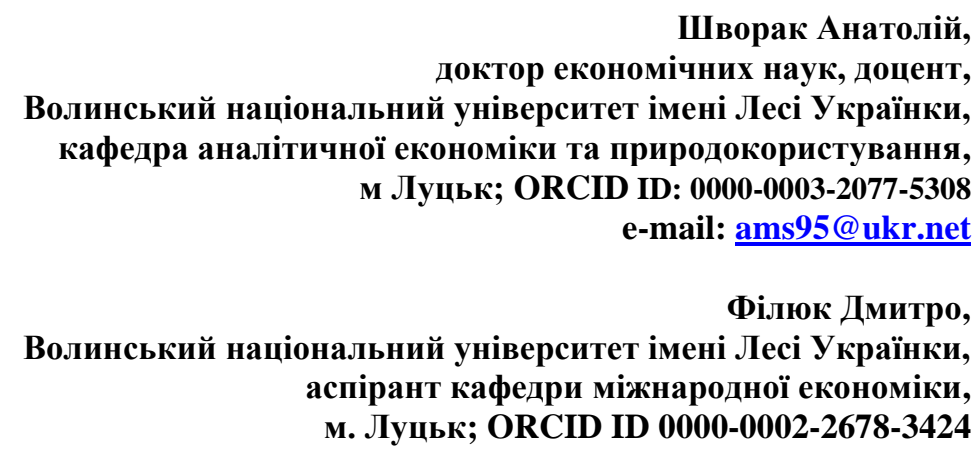

e-mail: $\underline{0666763009 @ u k r . n e t}$

https://doi.org/10.29038/2786-4618-2021-01-37-51

\title{
ВПЛИВ ЕКОСИСТЕМНИХ ПОСЛУГ НА АКТИВІЗАЦІЮ РОЗВИТКУ СІЛЬСЬКОГОСПОДАРСЬКОГО ВИРОБНИЦТВА
}

У статті проаналізовано ситуацію у сфері екосистемних послуг Волинської області та розглянута роль бджільництва в збільшенні потенційної продуктивності сільськогосподарського виробництва. Розкриті досягнення, проблеми і завдання екосистемних послуг на сучасному рівні розвитку сільськогосподарського виробництва. Доведено, що запилення медоносними бджолами ентомофільних культур найдешевший, найрезультативніший та екологічно чистий чинник зростання виробництва продукції рослинництва. Визначено пріоритети стратегій і планів дій, щодо соціально, економічно і екологічно збалансованого розвитку сільських територій, що спрямований на створення повноцінного життєвого середовища для сучасного та наступних поколінь на основі раціонального використання ресурсів. Відмічено, що реальні можливості сільського господарства України, зокрема рослинництва та бджільництва, задля зростання економічної ефективності та конкурентоспроможності галузей повинні складатися із найважливіших чинників які необхідно реалізувати за допомогою регіональних програм їх розвитку. Доведено, що Волинська область має високий потенціал у цій сфері, який в умовах підвищення ефективності функціонування вітчизняного агропромислового комплексу доцільно максимально використовувати. Розглянуто проблеми, які не дозволяють повною мірою використати можливості й досягти максимальної економічної ефективності в цих галузях. У статті звернено увагу на те, що ці проблеми є актуальними не лише для галузей аграрного виробництва, а й для сталого розвитку сільських територій.

Ключові слова: сільські території, економічна ефективність, екосистемні послуги, бджільництво, запилення, рослинництво, врожайність.

Шворак Анатолий, доктор экономических наук, доцент,

Волынский национальный университет имени Леси Украинки, кафедра аналитической экономики и природопользования, г. Луцк

Филюк Дмитрий, аспирант,

Волынский национальный университет имени Леси Украинки, кафедра международных экономических отношений. г. Луцк

\section{ВЛИЯНИЕ ЭКОСИСТЕМНЫХ УСЛУГ НА АКТИВИЗАЦИЮ РАЗВИТИЯ СЕЛЬСКОХОЗЯЙСТВЕННОГО ПРОИЗВОДСТВА}

В статье проанализирована ситуация в сфере экосистемных услуг Волынской области и рассмотрена роль пчеловодства в увеличении потенциальной продуктивности сельскохозяйственного производства. Раскрыты достижения, проблемы и задачи экосистемных услуг на современном уровне развития сельскохозяйственного производства. Доказано, что опыление медоносными пчелами энтомофильных культур дешевый, самый и 
экологически чистый фактор роста производства продукции растениеводства. Определены приоритеты стратегий и планов действий, по социально, экономически и экологически сбалансированного развития сельских территорий, направленный на создание полноценной жизненной среды для современного и будущих поколений на основе рационального использования ресурсов. Видмиченно, что реальные возможности сельского хозяйства Украины, в частности растениеводства и пчеловодства, для роста экономической эффективности и конкурентоспособности отраслей должны состоять из важнейших факторов, которые необходимо реализовать с помощью региональных программ их развития. Доказано, что Волынская область имеет высокий потенциал в этой сфере, который в условиях повышения эффективности функционирования отечественного агропромышленного комплекса целесообразно максимально использовать. Рассмотрены проблемы, которые не позволяют в полной мере использовать возможности и достичь максимальной экономической эффективности в этих областях. В статье обращено внимание на то, что эти проблемы актуальны не только для отраслей аграрного производства, но и для устойчивого развития сельских территорий.

Ключевые слова: сельские территории, экономическая эффективность, экосистемные услуги, пчеловодство, опыление, растениеводство, урожайность.

\section{Shvorak Anatoliy, \\ Doctor of Economics, Professor, Lesya Ukrainka Volyn National University, Department of AnalyticaEconomics and Nature Management, Lutsk \\ Filiuk Dmytro, PhD student, Lesya Ukrainka Volyn National University, Department of International Economic Relations, Lutsk}

\section{THE IMPACT OF ECOSYSTEM SERVICES ON THE INTENSIFICATION OF AGRICULTURAL PRODUCTION}

The article analyzes the situation in the field of ecosystem services of Volyn region and considers the role of beekeeping in increasing the potential productivity of agricultural production. Achievements, problems and tasks of ecosystem services at the current level of development of agricultural production are revealed. It has been proved that pollination of entomophytic crops by honey bees is the cheapest, most effective and ecologically clean factor of growth of crop production. The priorities of strategies and action plans for socially, economically and ecologically balanced development of rural areas, aimed at creating a full living environment for modern and future generations based on the rational use of resources. It is noted that the real opportunities of Ukraine's agriculture, in particular crop production and beekeeping, to increase economic efficiency and competitiveness of industries should consist of the most important factors that must be realized through the development of regional programs for their development. It is proved that Volyn region has a high potential in this area, which in terms of improving the efficiency of the domestic agroindustrial complex should be used to the maximum. Problems that do not allow to make full use of opportunities and achieve maximum economic efficiency in these areas are considered. The article draws attention to the fact that these problems are relevant not only for agricultural production, but also for sustainable development of rural areas.

Key words: rural areas, economic efficiency, ecosystem services, beekeeping, pollination, crop production, yield.

Актуальність дослідження. Біорізноманіття та екосистемні послуги є невід'ємною складовою, виробництва продовольчих товарів, а їх внесок в соціально, економічно і екологічно збалансований розвиток сільських територій та аграрного виробництва є базовим компонентом.

Для досягнення необхідного, особлива увага приділяється ролі запилювачів, а в цілому системи «запилення - рослинництво», стан і динаміка факторів їх зміни, що впливають на погіршення та недостатність запилення на виробництво продовольства є основою даного дослідження. Зокрема, потенціал біоресурсів, наявний в агропромисловому комплексі, зокрема рослинництві, на нашу думку, не цілком розкритий, тому доцільним є розгляд послуг екосистем, спрямованих на запилення ентомофільних рослин, які складають третину раціону людини. Управління запиленням можливе 
через менеджмент галузі бджільництва, як чинником зростання виробництва продукції рослинництва. Визначення пріоритетів стратегій i планів дій, щодо соціально, економічно $i$ екологічно збалансованого розвитку сільських територій, потребує визначення найважливіших чинників зростання економічної ефективності та конкурентоспроможності галузей. Вітчизняний агропромисловий комплекс дозволяє повною мірою використати потенційні можливості в досягненні сталого розвитку сільських територій.

Проблематика розвитку сільський територій та формування їх ефективності природо ресурсного потенціалу є предметом досліджень багатьох учених, зокрема, таких, як Бородіна О. [1], Поліщук В. [4], Мішенін С. [21], Шворак А. [25] та ін. Науковцями досліджено та узагальнено еволюцію процесів аграрного і сільського розвитку, розглянуто реалії й обгрунтовано перспективи політики сільського розвитку на базі громад в Україні. Сформовано теоретико-методичні засади та розробки конкретних пропозицій, спрямованих на забезпечення ефективного виробництва й реалізації продукції бджільництва в умовах ринку Проблематика дослідження сільських територій вже не одноразово вивчалась науковцями, проте з точки зору природо - ресурсного потенціалу в контексті синергетичного ефекту від бджільництва та рослинництва Волинської області, дослідження не проводились.

Мета і завдання статті. 3 огляду на вище означене, основною метою роботи є виокремлення ключових орієнтирів досягнення сталого розвитку як сільських територій так і забезпечення економічної ефективності сільськогосподарського виробництва.

Виклад основного матеріалу та обгрунтування отриманих результатів дослідження.

Сталий розвиток i конкурентоспроможність сільського розвитку, регіональних агропродовольчих систем залишаються одними з основних пріоритетів економічної політики нашої держави. Важливим, є пошук чинників спрямованих на відродження українського села та підвищення ефективності функціонування вітчизняного агропромислового комплексу.

Занепад села, його соціальної інфраструктури, банкрутство сільськогосподарських підприємств призводить до зубожіння сільського населення, погіршення здоров'я, як наслідок цього демографічна криза, продовольча проблема, старіння сільського населення, бідність. Виправлення ситуації потребує значних інвестицій, фінансових вливань та організаційних заходів. Тому необхідно зосередити увагу як на загальних проєктах розвитку окремих територій регіону, так і на розв'язанні локальних проблем, які допоможуть відкрити додаткові можливості розвитку села.

Особливу увагу сільськогосподарському виробництву та розвитку сільських територій приділяють міжнародні організації, зокрема Всесвітній банк і Продовольча та сільськогосподарська організація ООН (ФАО) стосовного того, що сільські територіальні одиниці мають за основу виключно традиційні види діяльності (сільгоспвиробництво, лісництво, бджільництво, рибальство та видобувну промисловість [22].

Також, слід зазначити, що питання раціонального використання природних ресурсів, у тому числі земельних, визначене концепцією сталого розвитку, яка передбачає взаємне узгодження екологічних, економічних і соціальних чинників розвитку. Концепція сталого розвитку прийнята в червні 1992 року у Ріо-де-Жанейро на Конференції ООН з навколишнього середовища і розвитку та орієнтована на підготовку світового співтовариства до розв'язання еколого - економічних i соціально - економічних проблем близького майбутнього [2].

Вимоги сьогодення трансформують підходи до процесів структурної побудови галузей у сільській місцевості, що знайшло відбиття у концепціях розвитку ЄС, оскільки в даній галузі пріоритетне спрямування має - диверсифікація системи господарювання в межах даних територій.

Взаємозв'язок розвитку сільських територій та сільськогосподарського виробництва виокремлюють вітчизняні науковці, зокрема В.Д. Невесенко розглядає сільський розвиток у площині розвитку суспільних сільських соціально-територіальних підсистем та досягнення найефективнішого використання потенціалу матеріально-фінансової, людської та інших систем ресурсного забезпечення, підвищення життєвого рівня населення, а також збільшення можливостей системи користування земельними ресурсами, як визначного економічного ресурсу територіальної громади та надійного джерела фінансових ресурсів [23].

Зокрема, цілком погоджуємось 3 думкою Бородіної, «водночас основою і сільського господарства, і сільського розвитку є населення, господарство, територія», а «людський потенціал 
галузі є вагомою частиною сільських громад, аграрне виробництво - вагомою частиною сільської економіки, а агроландшафти - переважаючий елемент облаштування сільської території», саме тому стратегічним орієнтиром для сільських територій $є$ підвищення рівня соціальної мобілізації населення в сфері підприємництва. А оскільки залишаючись основною галуззю у сільській місцевості, сільське господарство має більшою чи меншою мірою реалізувати економічні, соціальні та екологічні цілі сільського розвитку необхідно забезпечити повноцінні умови саме для галузі сільського господарства.[1]

Очевидний взаємозв'язок сільського господарства і сільського розвитку потребує узгодженого управління та має реалізуватися паралельно з економічними завданнями вирішувати ще соціально екологічні - як суто галузевого характеру, так і сільського розвитку, забезпечуючи синергетичний ефект.[1]

Особливе місце в соціально-економічному розвитку села займає виробництво продовольчих товарів, яке $\epsilon$ важливою матеріальною основою існування людства, оскільки відіграє значну роль у задоволенні його базової потреби у харчових продуктах. У багатьох країнах, зокрема і в Україні, розвиток цієї галузі вирішує не лише національні проблеми у забезпеченні суспільства харчовими продуктами, а й сприяє досягненню глобальної продовольчої безпеки.

Стратегічне спрямування сільського розвитку $\epsilon$ органічно пов'язаним із парадигмою зрівноваженого (сталого) розвитку, який має на меті збалансований розвиток основних складових: соціальної, економічної, екологічної та інституційної. Зазначимо, що до вивчення даного питання необхідно підходити комплексно, але 3 врахуванням регіональних особливостей. 3 метою, дослідження чинників, які сприяють забезпеченню поставлених вимог, основну увагу спрямовано на вивчення впливу синергетичного ефекту екосистемних послуг на аграрне виробництво Волинської області.

Сучасний стан Волинської області характеризується нерівномірністю соціально - економічного розвитку, за обсягами наявного ресурсного потенціалу й ефективністю його використання. Зокрема розвиток регіональних ринків праці значною мірою залежить від розміщення продуктивних сил, зумовленого наявними природними ресурсами, історичним розвитком і місцевими традиціями, та відображає економічну спеціалізацію регіонів країни.

На погляд С.В. Мішеніна, Н.В. Олійника екосистемні послуги доцільно визначати як економічні вигоди, які отримують економічні суб'єкти від використання існуючих функцій екосистем, а також таких, що утворюються в результаті генерування, відновлення, підтримки, регулювання екосистемних процесів, які формуються в результаті цілеспрямованої діяльності тих або інших суб’єктів господарювання різних форм власності та рівнів ієрархічного управління.[21]

Поряд 3 цим, згадані автори зазначають, що більшість визначень екосистемних послуг потребують проведення економічної (вартісної) ідентифікації екосистемних послуг.

Екосистемні послуги підтримки - послуги необхідні для підтримки інших екосистемних послуг. До підтримуючих належать запобігання опустеленню, грунтозахисні функції, збереження біорізноманіття, грунтоутворення, фотосинтез. Такі послуги впливають на добробут людей опосередковано, уможливлюючи формування потоків забезпечувальних, регулювальних i культурних послуг. Значна частина послуг екосистем не $\epsilon$ продуктами споживання чи предметами використання, вони споживаються людьми опосередковано, непрямо, але якість життя людей фундаментально залежить від потоку цих послуг.

Запилення рослин - одна 3 найбільш значимих екосистемних послуг, від якої залежить продовольча безпека людства та функціонування природних екосистем.

Внесок запилювачів у глобальну економіку оцінюється в 235 - 577 млрд на рік. Таких висновків 2016 року дійшли експерти міжнародної дослідницької групи IPBES, що працює на замовлення Міжнародної конвенції про охорону біологічного різноманіття. Зокрема робота запилювачів в Свропі оцінюється приблизно в 22 млрд. євро на рік. На відміну від багатьох інших екосистемних послуг, запилення можна відносно точно монетизувати, адже відома вартість продуктів, що отримані від комахозапильних рослин.

Таким чином, на наш погляд, екосистемні послуги - це сукупність функцій екосистем, які забезпечують збереження навколишнього природного середовища та створюють умови для підтримки й поліпшення життєдіяльності людини. Ми поділяємо думку дослідників про те, що, 
трансформуючись в екосистемні послуги, функції екосистем набувають економічної, соціокультурної та екологічної характеристик і забезпечують економічні вигоди як для споживачів, так і постачальників цих послуг.

Разом $з$ тим, дослідженнями вітчизняних науковців встановлено, що насіння ентомофільних культур, одержане при запиленні медоносними бджолами, має підвищені господарсько-корисні якості. Виходячи з вищесказаного та досвіду зарубіжних країн, бджолозапилення повинно бути узаконеним агрономічним прийомом технології вирощування ентомофільних сільськогосподарських культур.

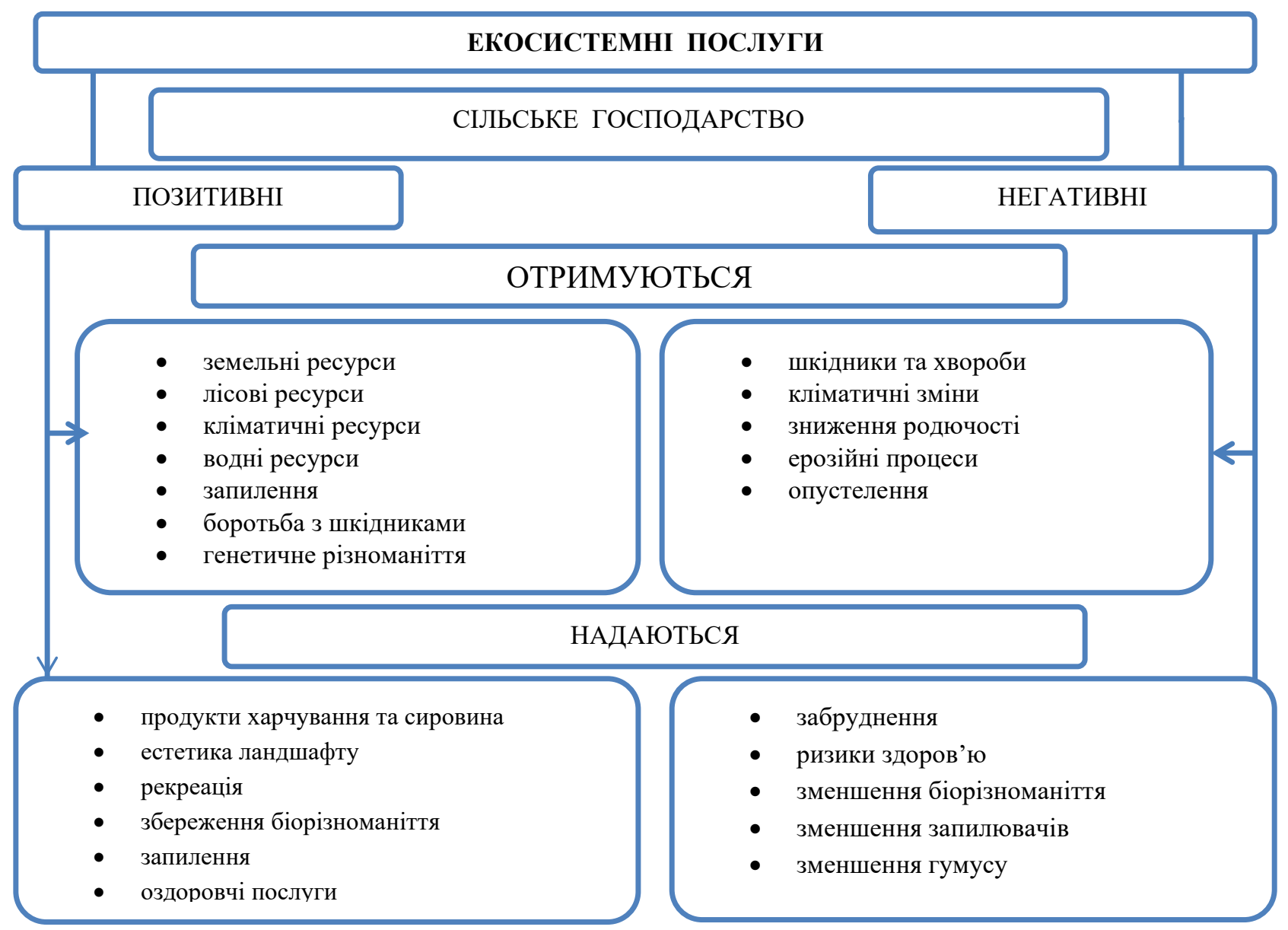

Рис. 1. Класифікачія екосистемних послуг в сільському господарстві [17], з доповненнями авторів

Біологічні ресурси в економіці необхідно розглядати через їх функціональність у процесі надання екосистемних послуг. Українська вчена Л. Д. Загвойська визначає поняття послуг екосистем як економічну категорію, прийняту «для позначення вкладу екосистем у добробут людини» [19].

3 огляду на те, що галуззю, де здебільшого застосовують потенціал біоресурсів, $\epsilon$ агропромисловий комплекс, зокрема рослинництво, на нашу думку, доцільним є розгляд послуг екосистем, спрямованих на запилення ентомофільних рослин, які складають третину раціону людини. Управління запиленням можливе через менеджмент галузі бджільництва. У цьому контексті доцільно врахувати й інші екологічні послуги бджільництва.

3 економічної точки зору, пасіка $\epsilon$ екологічною системою, в якій головним біотичним компонентом є популяція бджіл та яка вносить вклад у добробут людини, тобто надає екологічні послуги шляхом надання цінних продуктів бджільництва: мед, віск, пилок, прополіс, маточне молочко та ін. 
Таблиияя 1

Міжнародне порівняння оплати екосистемних послуг

\begin{tabular}{|c|c|c|c|}
\hline Регіон світу & Плата обов'язкова & Плата необов'язкова & Плата відсутня \\
\hline Європа & $\begin{array}{c}\text { Данія } \\
\text { Фінляндія } \\
\text { Італія } \\
\text { Норвегія } \\
\text { Швеція } \\
\text { Туреччина } \\
\text { Великобритація }\end{array}$ & $\begin{array}{c}\text { Бельгія } \\
\text { Франція } \\
\text { Румунія } \\
\text { Словаччина } \\
\text { Швейцарія } \\
\text { Польща }\end{array}$ & $\begin{array}{c}\text { Люксембург } \\
\text { Словенія } \\
\text { Боснія і Герцеговина } \\
\text { Албанія } \\
\text { Греція } \\
\text { Україна }\end{array}$ \\
\hline Америка & $\begin{array}{c}\text { Канада } \\
\text { Куба } \\
\text { США }\end{array}$ & - & - \\
\hline Африка & ПАР & - & $\begin{array}{c}\text { Гана } \\
\text { Кенія } \\
\text { Танзанія } \\
\text { Уганда }\end{array}$ \\
\hline Азія & $\begin{array}{c}\text { Індія } \\
\text { Ізраїль } \\
\text { Філіппіни }\end{array}$ & - & $\mathrm{B}^{\prime} є$ тнам \\
\hline
\end{tabular}

Джерело: Приклади застосування системи плати за запилення у різних країнах [18], з доповненнями авторів.

Але найголовніша роль екологічних послуг бджільництва для людства та для екосистеми планети в цілому полягає в їх здатності опилювати квіткові рослини. Зокрема, близько 80 відсотків відомих видів рослин в процесі еволюції рослинного світу пристосувались до перехресного запилення та утворюють насіння в результаті здійсненого перехресного запилення, причому 4/5 3 них потребують запилення комахами. [9] За даними В. П. Поліщука, медоносні бджоли запилюють близько $-80 \%$ ентомофільних рослин, інші комахи - 18\%, вітром запилюється $-2 \%$. [4]

Зокрема, законодавство України, що регламентує діяльність у сільському господарстві, та зокрема бджільництві орієнтоване на гармонійне поєднання та розвиток. Так, відповідно до Закону України «Про бджільництво», бджільництво - галузь сільськогосподарського виробництва, основою функціонування якої є розведення, утримання та використання бджіл для запилення ентомофільних рослин сільськогосподарського призначення і підвищення їх урожайності, виробництво харчових продуктів і сировини для промисловості. Крім того, здійснення контролю за ефективністю запилення ентомофільних рослин сільськогосподарського призначення у відповідності до статті 7 даного закону відноситься до державного регулювання. [7]

Використання бджіл, унормоване вищевказаним Законом дозволяє використання, зокрема для запилення ентомофільних дикорослих рослин, запилення і підвищення врожайності ентомофільних рослин сільськогосподарського призначення та виробництва продуктів бджільництва. При цьому, фізичні та юридичні особи, які вирощують ентомофільні рослини сільськогосподарського призначення, для підвищення урожайності цих рослин можуть використовувати пасіки на договірних засадах.

3 метою, забезпечення запилення ентомофільних культур органи Державної автомобільної інспекції Міністерства внутрішніх справ України сприяють безперешкодному перевезенню (кочівля - підвіз пасік на медозбір і запилення ентомофільних рослин) пасік. У разі необхідності вони організовують їх супровід до пунктів призначення.[7]

Законодавча термінологія, визначає, що ентомофільні рослини сільськогосподарського призначення - рослини, які запилюються комахами. Українська держава робить певні кроки щодо розвитку та захисту галузі бджільництва, зокрема 3 метою охорони бджіл у разі застосування в сільському і лісовому господарстві засобів захисту рослин, дозволяється тільки згідно з переліком затвердженим у відповідності до норм чинних нормативних актів.[7] 
За таких інституційно - організаційних засад, цілком доцільно впроваджувати подальше планомірне використання природо - ресурсного потенціалу рослинництва для потреб галузі бджільництва. Зокрема для аналізу наявних ресурсів та їх оцінки необхідно забезпечити наявність достовірних даних для виявлення сучасного стану та тенденції розвитку обох галузей. Системна економічна та екологічна оцінка типів рослинних медодайних ресурсів становить значний інтерес 3 позиції найдинамічнішого чинника розвитку галузі бджільництва.

Зокрема, для дослідження впливу синергетичного ефекту відекосистемних послуг на економічний потенціал сільськогосподарського виробництва у Волинській області, було застосовано наступний алгоритм, що включав такі операції:

постановка мети і формулювання завдання дослідження визначення впливу екосистемних послуг;

збір статистичної інформації, щодо показників нектарної продуктивності основних ентомофільних медоносних рослин, та аналітичні дані їх видового складу, повноти, продуктивності тощо;

збір інформації про науково - обгрунтовану норму запилення ентомофільних культур;

збір інформації про середні показники врожайності ентомофільних культур;

систематизація зібраної інформації, її обробка, аналіз та узагальнення;

вибір методів і прийомів дослідження:запилення та медової продуктивності ентомофільних культур;

вибір об'єктів детального дослідження економічного потенціалу аграрного виробництва;

обгрунтування пропозицій щодо використання результатів дослідження у практиці формування економічної ефективності суб'єктів господарювання в системі аграрного виробництва;

реалізація результатів дослідження надання екосистемних послуг у бджільництві, лісовому господарстві та теоретичних узагальненнях в контексті сталого розвитку сільських територій.

Зокрема, з метою встановлення стану чисельності бджолиних родин у Волинській області, було використано показник усередненої щільності бджолиних родин на квадратний кілометр, результати дослідження наведено у діаграмі 1.

Показник, щільності бджолиних сімей в розрізі областей за 2019 рік *

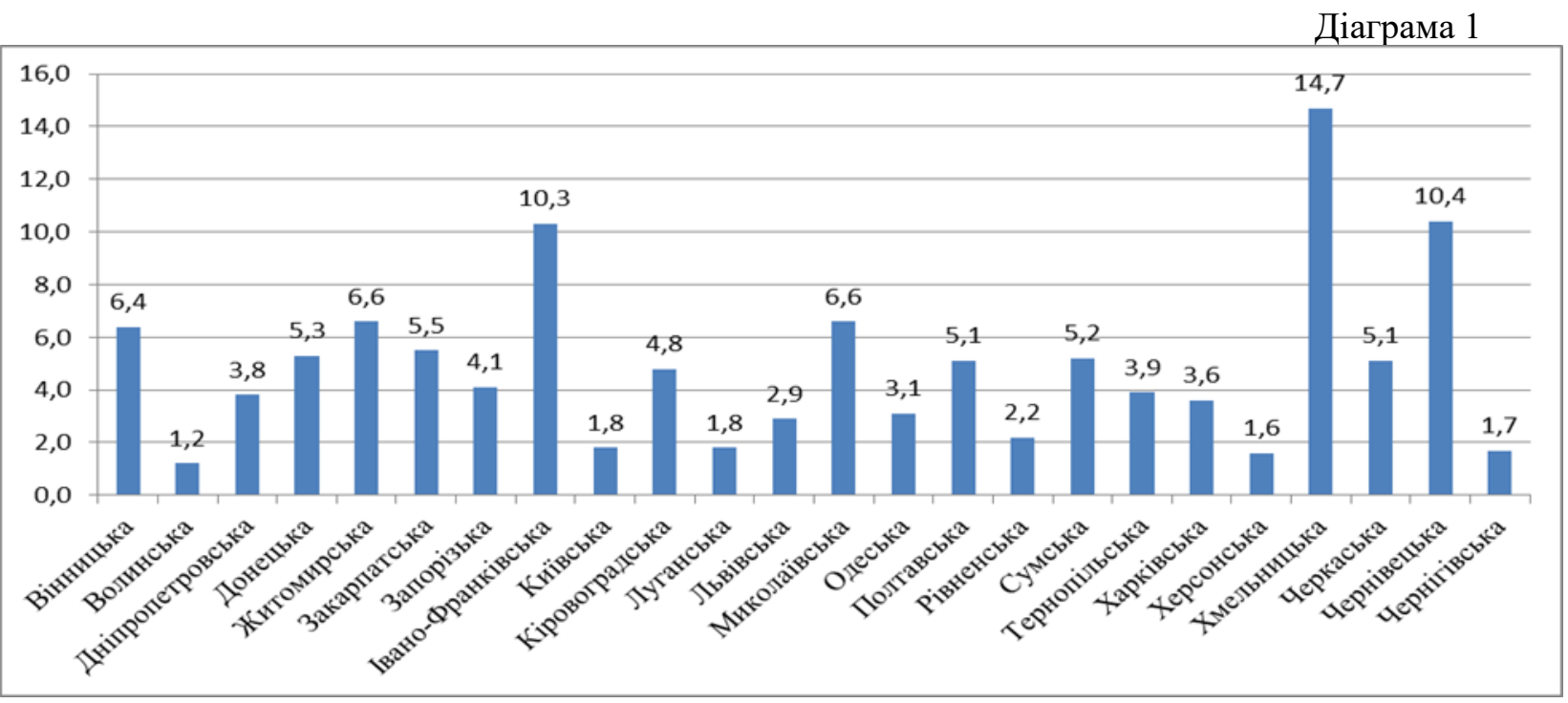

* Розраховано авторами самостійно за даними:http://www.ukrstat.gov.ual

Встановлено, усереднений показник щільності бджільництва в Україні який становить - 4,5 бджолиних родин на квадратний кілометр. Зокрема, найменша чисельність бджолиних родинна квадратний кілометр, спостерігається у Волинської області, а саме - 1,2 б. р., що у 3,75 рази менше середнього показника по країні, так і загальна чисельність бджолиних родин в області найнижча по країні та становить лише 24,0 тис бджолосімей або 0,93 відсотка. 
Той факт, що найнижча чисельність бджолиних родин та показник чисельності б. р. на квадратний кілометр у Волинській області, свідчить про відставання галузі від усереднених показників по Україні та недостатню ефективність запилення ентомофільних рослин та використання наявних нектарних ресурсів.

Встановлення показника продуктивності з однієї бджолиної родини, дозволяє встановити рівень розвитку бджільництва у Волинській області. Зокрема, про важливість показника продуктивності виробництва меду з однієї бджолиної сім'ї вказує німецький вчений проф. К. Бінефельд, який впродовж 23 років вивчав при статистичній вибірці в 5,7 тис. бджолиних родин їх продуктивність. Результати свідчать про повільне зростання продуктивності - 0,25 кг. меду/рік, що типово для результатів селекції інших тварин, наприклад, у курей - 1 яйце/рік. При цьому збільшення продуктивності відбувається не по окремих бджолиних родинах, а за рахунок середньої продуктивності всієї пасіки.[20] Збільшення середньої продуктивності пасіки, відбувається, за рахунок визначення кормової бази місцевості і кількості б. р. необхідних для ефективного використання наявних ресурсів.

За даними (діаграми 2), встановлено, що середня продуктивність виробництва меду з однієї бджолиної сім'ї у Волинській області у 2019 році становила 12,9 кг, (середній показник по Україні становить 26,9 кг.). Низька продуктивність б. р. свідчить про низький рівень впровадження методів і прийомів, які грунтуються на науковій організації праці та використанні прогресивного досвіду розвинених країн і досягнень аграрної та економічної наук у даній сфері.

Показник, продуктивності однієї бджолиної родини в розрізі областей, у 2019 році, (кг. меду)

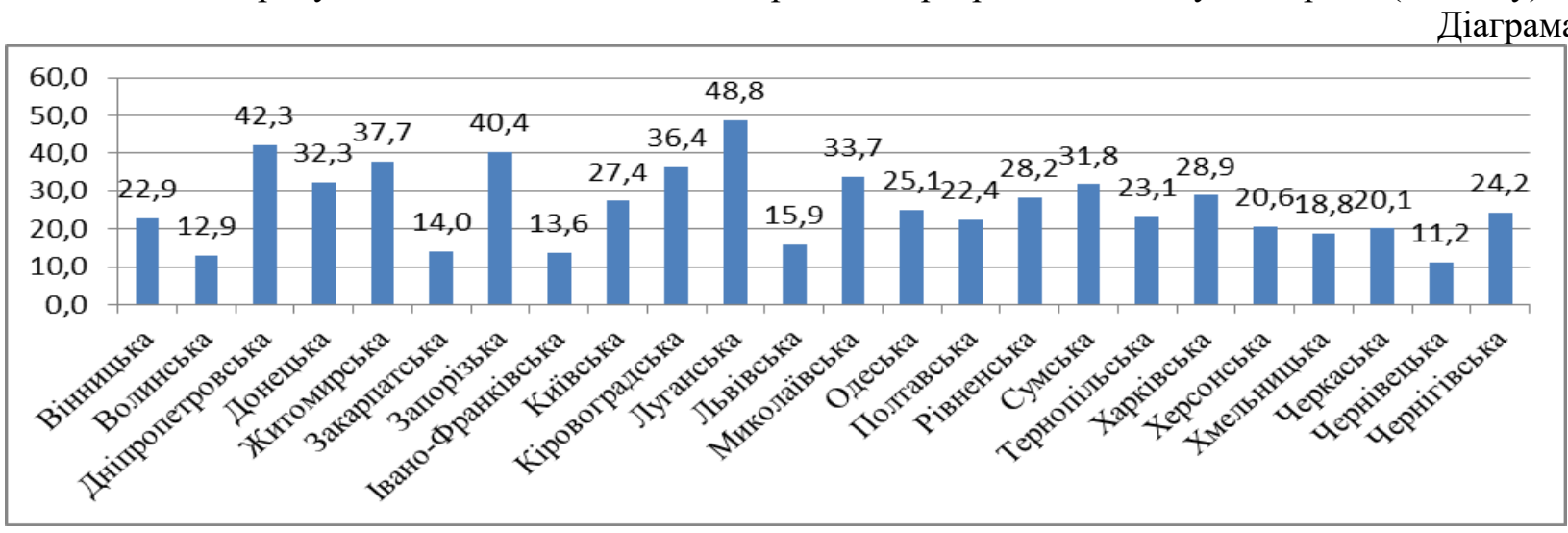

* Розраховано авторами самостійно за даними:http://www.ukrstat.gov.ua/

Показник виробництва меду у розрахунку на одну особу в Україні у 2019 році, кг.

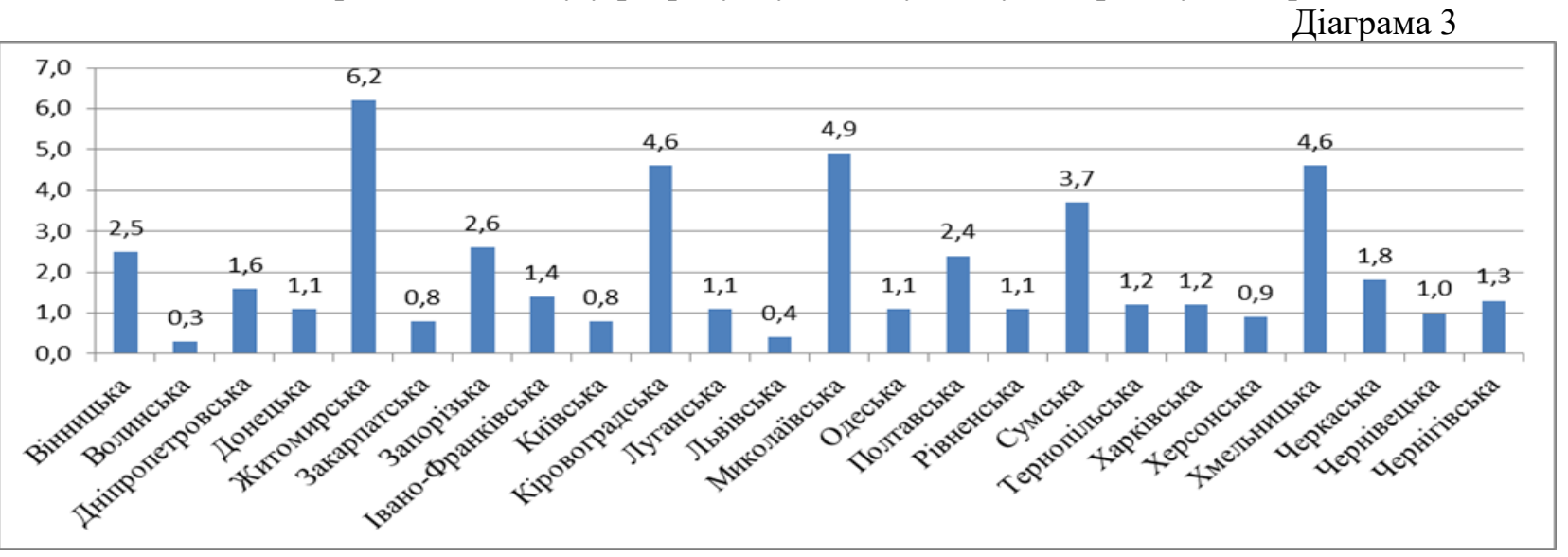

* Розраховано авторами самостійно відповідно з http://www.ukrstat.gov.ua/ 
Виробництво меду у Волинській області становить 0,4 \%, або 310,0 тонн до всього виробленого меду у державі у 2019 році. Середній показник виробництва меду у розрахунку на одну особу в Україні становить 1,8 кг меду, найбільше виробляють меду в розрахунку на одного жителя у Житомирській області - 6,2 кг меду, найменше виробляють меду в розрахунку на одного жителя у Волинській області - 0,3 кг меду.

Враховуючи, науково - обгрунтовану норму споживання меду з усього набору продуктів харчування для дітей та працездатного населення на рік яка має становити не менше 1,1 кг, показник виробництва меду на одного жителя у Волинській областів 3 рази менший від норми споживання.

Проведений аналіз свідчить, про низький стан розвитку галузі бджільництва Волинської області у співставленні до основних показників діяльності бджільництва в Україні та потребує комплексного підходу до врегулювання питання ефективної господарської діяльності.

Таблиця 2

\section{Вплив екосистемних послуг на ефективність сільськогосподарського виробництва}

\begin{tabular}{|c|c|c|c|c|c|c|c|c|c|c|c|c|}
\hline \multirow{2}{*}{$\begin{array}{c}\text { Сільськогосподарська } \\
\text { культура }\end{array}$} & \multicolumn{2}{|c|}{ Площа, га } & \multicolumn{2}{|c|}{$\begin{array}{c}\text { Врожайність, } \\
\text { ц./га }\end{array}$} & \multicolumn{2}{|c|}{$\begin{array}{c}\text { Потенційне } \\
\text { зростання за } \\
\text { умови } \\
\text { запилення }\end{array}$} & \multirow{2}{*}{$\begin{array}{l}\text { Норма } \\
\text { запил. } \\
\text { б.д./га }\end{array}$} & \multirow{2}{*}{$\begin{array}{c}\text { Медова } \\
\text { прод., } \\
\text { кг/га* }\end{array}$} & \multicolumn{2}{|c|}{ Запас меду, кг } & \multicolumn{2}{|c|}{$\begin{array}{c}\text { Потреба: кількість } \\
\text { бджолородин, од. }\end{array}$} \\
\hline & площа, & $\begin{array}{c}\text { вал. збір } \\
\text { тис. } \mathrm{m} / 2 а\end{array}$ & $\begin{array}{l}\text { факт } \\
\text { ична }\end{array}$ & $\left|\begin{array}{c}\text { потениій } \\
н а\end{array}\right|$ & $\%$ & $4 . / 2 a$ & & & біолог. & факт. & \begin{tabular}{|c} 
для \\
рослиннич \\
тва \\
\end{tabular} & $\begin{array}{c}\text { для } \\
\text { бджільниц } \\
\text { тва } \\
\end{array}$ \\
\hline 1 & 2 & 3 & 4 & 5 & 6 & 7 & 8 & 9 & 10 & 11 & 12 & 13 \\
\hline $\begin{array}{c}\text { Культури зернові та } \\
\text { зернобобові: } \\
\end{array}$ & 298,90 & 1292,6 & 43,4 & $\mathbf{x}$ & $\mathbf{x}$ & $\mathbf{x}$ & $\mathbf{x}$ & $\mathbf{x}$ & $\mathbf{x}$ & $\mathbf{x}$ & 10980,0 & 1326,8 \\
\hline пшениия & 153,90 & 712,1 & 43,9 & $33,3-125$ & $x$ & $x$ & $x$ & $x$ & $x$ & $x$ & $x$ & $x$ \\
\hline жито & \begin{tabular}{|l|}
24,10 \\
\end{tabular} & 56,7 & 26,6 & $28-55$ & $x$ & $x$ & $x$ & $x$ & $x$ & $x$ & $x$ & $x$ \\
\hline тритикале & 3,10 & 13,7 & 35,7 & $51,1-54,9$ & $x$ & $x$ & $x$ & $x$ & $x$ & $x$ & $x$ & $x$ \\
\hline овес & 38,10 & 83,0 & 21,8 & $43,5-70$ & $x$ & $x$ & $x$ & $x$ & $x$ & $x$ & $x$ & $x$ \\
\hline ячмінь & 33,50 & 114,0 & 34,0 & $46-84,6$ & $x$ & $x$ & $x$ & $x$ & $x$ & $x$ & $x$ & $x$ \\
\hline кукурудза & 32,00 & 296,3 & 93,3 & 136,0 & $x$ & $x$ & $x$ & $x$ & $x$ & $x$ & $x$ & $x$ \\
\hline гречка & 1,40 & 1,5 & \begin{tabular}{|l|}
10,6 \\
\end{tabular} & $16,8-32,8$ & $50-60$ & 5,8 & $2,-5$ & $80-224$ & 212800 & 106400 & 4900 & 952 \\
\hline просо & 1,10 & 1,9 & 19,0 & $28,3-35$ & $x$ & $x$ & $x$ & $x$ & $x$ & $x$ & $x$ & $x$ \\
\hline Зернобобові з них: & 5,30 & 13,4 & \begin{tabular}{|l|}
25,9 \\
\end{tabular} & $\mathbf{x}$ & $\mathbf{x}$ & $\mathbf{x}$ & $\mathbf{x}$ & $\mathbf{x}$ & $\bar{x}$ & $\mathbf{x}$ & $\bar{x}$ & $\mathbf{x}$ \\
\hline $2000 x$ & 3,30 & 10,4 & 31,6 & $29,3-50,2$ & 20,0 & 6,3 & 1,6 & $7-10,5$ & 28875 & 14438 & 5280 & 129 \\
\hline вика & 0,50 & $x$ & $x$ & $x$ & & & 1,6 & $20-200$ & 55000 & 27500 & 800 & 246 \\
\hline Культури технічні у т. ч: & 132,50 & 749,4 & $\mathbf{x}$ & $\mathbf{x}$ & $\mathbf{x}$ & $\mathbf{x}$ & $\mathbf{x}$ & $\mathbf{x}$ & $\mathbf{x}$ & $\mathbf{x}$ & \begin{tabular}{|l|}
128900,0 \\
\end{tabular} & 25894,5 \\
\hline буряк иукровий & 9,20 & 411,7 & 446,0 & $375-445$ & $x$ & $x$ & $x$ & $x$ & $x$ & $x$ & & \\
\hline ріпак $і$ кольза & 52,30 & 154,2 & 29,6 & $24,3-39,9$ & 25,0 & 7,4 & $2,0-4$ & $50-120$ & 4445500 & 2222750 & 104600 & 19881 \\
\hline $\cos$ & 36,20 & 88,8 & 24,6 & $30-49$ & 75,0 & 18,5 & 1,5 & & & & & \\
\hline сонящник & 31,90 & 94,5 & 30,1 & $24,5-37,6$ & $25-30,2$ & 8,3 & $0,5-1$ & 40,0 & 1276000 & 638000 & 23925 & 5707 \\
\hline гірчиия & 0,50 & 0,2 & 4,3 & $20-25$ & 25,0 & 1,1 & $0,5-1$ & $90-184$ & 68500 & 34250 & 375 & 306 \\
\hline $\begin{array}{l}\text { Картопля, культури } \\
\text { овочеві та баштанні }\end{array}$ & 90,40 & 281,9 & $\mathbf{x}$ & $\mathbf{x}$ & $\mathbf{x}$ & $\mathbf{x}$ & $\mathbf{x}$ & $\mathbf{x}$ & $\mathbf{x}$ & $\mathbf{x}$ & 13158,0 & 1586,5 \\
\hline картопля & 77,40 & $x$ & 175,0 & 199-320 & $x$ & $x$ & $x$ & $x$ & $x$ & $x$ & $x$ & $x$ \\
\hline $\begin{array}{c}\text { культури овочеві відкритого } \\
\text { грунту(без насінників) }\end{array}$ & 12,90 & 281,9 & 218,0 & $x$ & $7,0-65$ & 78,5 & $0,3-2$ & $13-42$ & 354750 & 177375 & 13158 & 1587 \\
\hline Культури кормові у. т. ч.: & 71,90 & 758,1 & $\mathbf{x}$ & $\mathbf{x}$ & $\mathbf{x}$ & $\mathbf{x}$ & $\mathbf{x}$ & $\mathbf{x}$ & $\mathbf{x}$ & $\mathbf{x}$ & 49400,0 & 4418,6 \\
\hline коренеплоди кормові & 11,40 & 333,3 & 292,1 & $x$ & $x$ & $x$ & $x$ & $x$ & $x$ & $x$ & $x$ & $x$ \\
\hline кукурудза кормова & 7,10 & 215,9 & 297,0 & $x$ & $x$ & $x$ & $x$ & $x$ & $x$ & $x$ & $x$ & $x$ \\
\hline трави однорічні & 10,40 & 35,5 & 41,4 & $50-70$ & $x$ & $2,5-3$ & $1,0-9$ & $20-150$ & 208000 & 104000 & 10400 & 930 \\
\hline трави багаторічні & 39,00 & 173,4 & \begin{tabular}{|l|}
47,3 \\
\end{tabular} & $120-140$ & $x$ & $2,5-3$ & $1,0-9$ & $20-150$ & 780000 & 390000 & 39000 & 3488 \\
\hline Культури зерняткові з них: & 1,40 & 26,8 & 189,0 & $\mathbf{x}$ & $\mathbf{x}$ & $\mathbf{x}$ & $\mathbf{x}$ & $\mathbf{x}$ & $\mathbf{x}$ & $\mathbf{x}$ & 4250,0 & 212,4 \\
\hline яблуня & 1,10 & 22,6 & 190,5 & $350-400$ & $38-41$ & 75,2 & $2,0-5$ & 40,0 & 44000 & 22000 & 3850 & 197 \\
\hline груиа а & 0,20 & 4,2 & 181,5 & $200-300$ & $25-30$ & 49,9 & 2,0 & $15-20$ & 3500 & 1750 & 400 & 16 \\
\hline Культура кісточкові з них: & 1,30 & 7,6 & 53,1 & $\mathbf{x}$ & $\mathbf{x}$ & $\mathbf{x}$ & $\mathbf{x}$ & $\mathbf{x}$ & $\mathbf{x}$ & $\mathbf{x}$ & 7800 & 566 \\
\hline слива & 0,40 & 2,0 & 54,1 & $200-300$ & $25-30$ & 14,9 & $2,0-2,5$ & $10,0-20,0$ & 6000 & 3000 & 900 & 27 \\
\hline вииня & 0,70 & 4,0 & \begin{tabular}{|l|}
56,7 \\
\end{tabular} & $60-120$ & 65,0 & 36,9 & $3,0-4$ & 35,0 & 24500 & 12250 & 2450 & 110 \\
\hline черешня & 0,10 & 0,3 & 32,3 & $100-250$ & $25-50$ & 12,1 & 3,0 & $36-40$ & 3800 & 1900 & 300 & 17 \\
\hline абрикос & 0,10 & 0,3 & \begin{tabular}{|l|}
42,2 \\
\end{tabular} & $150-250$ & $25-30$ & 11,6 & 3,0 & $25-40$ & 3250 & 1625 & 300 & 15 \\
\hline $20 p i x$ & 0,20 & 1,0 & \begin{tabular}{|l|}
59,7 \\
\end{tabular} & $25-210$ & $x$ & $x$ & 1,0 & $x$ & $x$ & $x$ & 200,0 & 0,0 \\
\hline Культури ягідні з них: & 1,30 & 4,9 & \begin{tabular}{|l|}
38,2 \\
\end{tabular} & $x$ & $x$ & $\mathrm{x}$ & $x$ & $\mathrm{x}$ & $x$ & $\mathbf{x}$ & 3650,0 & 398,3 \\
\hline суниці та полуниці & 0,30 & 2,7 & \begin{tabular}{|l|}
77,3 \\
\end{tabular} & $150-180$ & $50-75$ & 48,3 & $3,0-4,0$ & $6,5-10$ & 2475 & 1238 & 930 & 11 \\
\hline малина и ожина & 0,20 & 0,8 & \begin{tabular}{|l|}
61,6 \\
\end{tabular} & $100-120$ & 66,9 & 41,2 & $1,2-5$ & $57,1-199,8$ & 25690 & 12845 & 620 & 115 \\
\hline смородина & 0,70 & 1,3 & 21,4 & $120-150$ & 48,7 & 10,4 & $3,0-4$ & $24-150$ & 60900 & 30450 & 2100 & 272 \\
\hline Bинограd & 0,03 & 259,0 & \begin{tabular}{|l|}
83,4 \\
\end{tabular} & $75-85$ & $10,0-40,0$ & 20,9 & 1,0 & 0,0 & 0 & 0 & 0 & 0 \\
\hline ВСЬОГО & 603,0 & 3393,7 & $\mathbf{X}$ & 136,0 & $\mathbf{X}$ & $\mathbf{X}$ & $\mathbf{X}$ & $\mathbf{x}$ & 7429425 & \begin{tabular}{|l|}
3714713 \\
\end{tabular} & 218138 & 34403 \\
\hline
\end{tabular}

Джерело : Складено авторами самостійно за · [3,4,5,6,9,11,12,13,14,15,16] 
За даними таблиці 2, встановлено забезпеченість бджолиних сімей кормовою базою та розрахунок забезпеченості бджолиними сім'ями посівів основних ентомофільних сільськогосподарських культур для їх повноцінного запилення.

Зокрема, зведена потреба в бджолиних родинах для повноцінного запилення, 3 врахуванням науково - обгрунтованої норми кількості бджолиних родин на гектар становить - 218,1 тис бджолиних родин. При цьому, зазначені посіви та насадження сільськогосподарських культур формують кормовий ресурс, який дозволяє утримувати тільки - 34,4 тис бджолиних родин.

Однак, при досліджені нами впливу синергетичного ефекту лісівництва і бджільництва на розвиток сільських територій Волинської області, було встановлено, що природо - ресурсний потенціал лісової медоносної бази Волині становить 4,5 тис. тонн нектару, а для досягнення максимального використання цього ресурсу необхідно забезпечити в області наявність 40,3 тис. бджолиних родин.[25]

Зокрема, результати досліджень, свідчать про наявність факторів підвищення економічної ефективності бджільництва на основі максимально повного та продуктивного використання медодайних та пилкодайних ресурсів наявних в області, що дозволить утримувати чисельність бджолиних родин в кількості - 74,7 тис. родин. Відтак, встановлена диспропорція між потребою у запиленні ентомофільних культур та кількістю бджолиних родин яку здатна утримати дані ресурси, становить - 143,4 тис б. р., даний факт, свідчить про наявний значний попит на екосистемні послуги у запиленні комахами сільськогосподарських культур в області.

Запилення посівів ентомофільних культур бджолами не тільки збільшує їх врожайність, але й покращує життєдайність їх наступних поколінь з одночасним зростання якості самих плодів. Врожаї сільськогосподарських культур за достатньої ефективності запилення бджолами, зростають в середньому на 30-50 відсотків. [6] Виробництво цінного продукту - меду описує Клименкова «Життедіяльність медоносних бджіл тісно пов'язана з квітковими рослинами, виділений рослинами в крихітній кількості нектар здатні зібрати та зберегти про запас тільки медоносні бджоли. Не було б бджіл, людство втратило би цінний дарунок природи» [3]

Зокрема, значення рослин для бджільництва зумовлене їхньою нектарною продуктивністю, адже нектарна продуктивність - це показник якості оцінки нектароносності рослин, за яким визначають кількість виділеного нектару, його біологічний запас. Найбільш активну оцінку дає показник ресурсів нектару суцільного масиву рослин на площі 1 га, виражений в кілограмах меду. В такому випадку використовують рівнозначний термін медопродуктивність. [4]

Серед факторів підвищення економічної ефективності бджільництва виняткову актуальність має такий чинник як максимально повне використання обмежених кормових ресурсів бджільництва. Детальніше, досліджено економічний потенціал впровадження планомірного надання екосистемних послуг, зокрема основних ентомофільних культур та вплив на зростання продуктивності в контексті потенційної врожайності сільськогосподарських культур.

При цьому зазначимо, що всі автори стверджують про додатковий ефект від бджільництва в національному господарстві, що базується на отриманні додаткового продукту завдяки підвищенню врожайності через запилення квіткових рослин. Більше того, економічний ефект виникає від покращання умов господарювання, які можуть отримувати всі сфери АПК на основі екологічних послуг бджільництва. Але, існуючі дисбаланси у системі управління біоресурсами в Україні поки не створюють належного середовища для підвищення ефективності даної галузі АПК. [24]

Тому, вважаємо за необхідне встановити стан та перспективи сільськогосподарського виробництва за умови надання екосистемних послуг.

За даними таблиці 3, встановлено, що за умови впровадження планомірного застосування запилення ентомофільних культур, потенційний приріст валового збору основних культур становитиме - 103,3 тис. тонн, що у вартісній оцінці становить - 107 753,6 тис. гривень.

Встановлена помісячна потреба у бджолиних родинах для запилення ентомофільних сільськогосподарських культур зображена на діаграмі 4, свідчить про значні коливання в наданні екосистемних послуг. Збалансування, можливе за рахунок використання всього природо ресурсного потенціалу придатного для бджільництва у Волинській області. 
Таблицяя 3

Потенційне зростання продуктивності сільськогосподарських культур від впровадження запилення

\begin{tabular}{|c|c|c|c|c|c|c|c|c|c|}
\hline \multirow{2}{*}{$\begin{array}{c}\text { Сільськогосп } \\
\text { одарська } \\
\text { культура }\end{array}$} & \multirow{2}{*}{ Площа, га } & \multicolumn{3}{|c|}{ Валовий збір тис. тонн. } & \multicolumn{4}{|c|}{ Вартісна оцінка, тис. грн } & \multirow{2}{*}{$\begin{array}{l}\text { Потреба, } \\
\text { б. р., од. }\end{array}$} \\
\hline & & $\begin{array}{c}\text { фактичн } \\
\text { ий }\end{array}$ & $\begin{array}{c}\text { потенцій } \\
\text { ний }\end{array}$ & $+/-$ & $\begin{array}{c}\text { ціна } \\
\text { за } \\
\text { тонну }\end{array}$ & к6 * к3 & к6 * к4 & $+/-$ & \\
\hline 1 & 2 & 3 & 4 & 5 & 6 & 7 & 8 & 9 & 10 \\
\hline смородина & 700 & 1,3 & 2,2 & 0,9 & 26,5 & 3440,6 & 5895,3 & 2454,8 & 2100 \\
\hline абрикос & 100 & 0,3 & 0,5 & 0,2 & 26,5 & 794,0 & 1424,0 & 630,0 & 300 \\
\hline слива & 400 & 2,0 & 2,8 & 0,8 & 26,5 & 5293,2 & 7302,2 & 2009,0 & 900 \\
\hline вишня & 700 & 4,0 & 6,5 & 2,5 & 26,5 & 10586,3 & 17332,1 & 6745,7 & 2450 \\
\hline яблуня & 1100 & 22,6 & 29 & 6,6 & 26,5 & 59812,7 & 77365,4 & 17552,7 & 3850 \\
\hline черешня & 100 & 0,3 & 0,4 & 0,1 & 26,5 & 794,0 & 1175,4 & 381,4 & 300 \\
\hline груша & 200 & 4,2 & 5 & 0,4 & 26,5 & 11115,6 & 12249,0 & 1133,4 & 400 \\
\hline ріпак і кольза & 52300 & 154,2 & 193,5 & 39,3 & 9,4 & 145131,5 & 182129,7 & 36998,2 & 104600 \\
\hline гірчиця & 500 & 0,2 & 0,3 & 0,1 & 0,0 & 0,0 & 0,0 & 0,0 & 375 \\
\hline $\begin{array}{l}\text { суниці та } \\
\text { полуниці }\end{array}$ & 300 & 2,7 & 3,8 & 1,1 & 26,5 & 7145,8 & 9973,3 & 2827,5 & 930 \\
\hline $\begin{array}{c}\text { малина й } \\
\text { ожина }\end{array}$ & 200 & 0,8 & 2,1 & 1,3 & 26,5 & 2117,3 & 5441,9 & 3324,7 & 620 \\
\hline $\begin{array}{c}\text { культури } \\
\text { овочеві } \\
\text { відкритого } \\
\text { грунту(без } \\
\text { насінників) }\end{array}$ & 12900 & 281,9 & 300,9 & 19,0 & 5,4 & 150861,6 & 161032,5 & 10170,9 & 13158 \\
\hline горох & 3300 & 10,4 & 12,5 & 2,1 & 3,7 & 3863,4 & 4648,6 & 785,2 & 5280 \\
\hline гречка & 1400 & 1,5 & 2,3 & 0,8 & 3,7 & 557,2 & 854,5 & 297,3 & 4900 \\
\hline соняшник & 31900 & 94,5 & 122,5 & 28,0 & 8,0 & 75689,8 & 98132,6 & 22442,8 & 23925 \\
\hline ВСБОГО & 106100,0 & 580,9 & 684,2 & 103,3 & $\mathbf{x}$ & 477202,8 & 584956,5 & 107753,6 & 164088,0 \\
\hline
\end{tabular}

Зведена помісячна потреба в бджолиних родинах, для запилення ентомофільних культур.

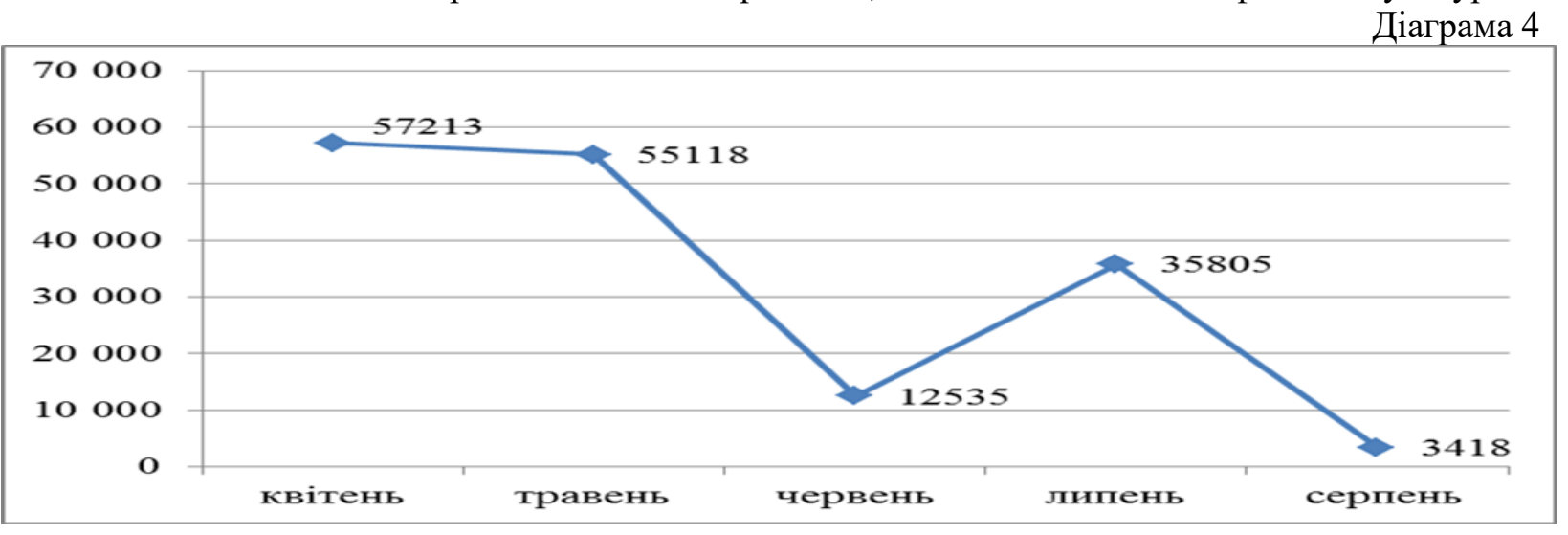

Висновки і перпективи подальших досліджень. Отримані наукові результати дають підстави для таких висновків:

Проведене, дослідження дозволило встановити, що найдешевший, найрезультативніший та екологічно чистий чинник зростання виробництва сільськогосподарської продукції це наявність позитивних екосистемних послуг, а зокрема тих, що надаються бджільництвом.

Запропоновано одним із стратегічних напрямів досягнення цілей сталого розвитку сільських територій використати синергетичний ефект від поєднання рослинництва з бджільництвом, 
економічна ефективність яких формується на основі максимально повного використання обмежених ресурсів, та є резервом збільшення виробництва продукції.

Зокрема, на основі даних таблиці 2, встановлено, що для досягнення зростання показника потенційного виробництва сільськогосподарської продукції, необхідно досягнути розвитку галузі бджільництва в частині збільшення чисельності бджолиних родин до показника - 218,1 тис. бджолосімей в області. Водночас, досліджені нами наявні кормові ресурси в області, що придатні для утримання бджолиних родин, дозволяють утримувати в області лише - 74,7 тис бджолиних родин.

Наявна ж чисельність, бджолиних родин складає всього - 24,0 тис бджолиних родин, а показник достатності запилення ентомофільних культур становить всього - $11 \%$, виробництво меду на одну особу в області - 0,3 кілограма.

Сучасний стан галузі бджільництва, у Волинській області потребує негайного втручання зі сторони держави та органів місцевого самоврядування, оскільки за підсумками 2019 року, в рейтингу регіонів область посідає:

- 24 -місце у рейтинговому списку по показнику чисельності бджолиних родин;

- 24 - місце у рейтинговому списку по показнику кількості виробленого меду;

- 23 - місце у рейтинговому списку по показнику середньої продуктивності однієї бджолиної родини;

- 24 - місце у рейтинговому списку по показнику середнього виробництва меду на одного жителя;

- 24 - місце у рейтинговому списку по показнику середньої щільності бджолиних родин на 1 квадратний кілометр.

Такий, аналіз свідчить, про низький стан розвитку галузі бджільництва у Волинській області у співставленні до основних показників діяльності бджільництва в Україні та потребує комплексного підходу до вирішення питання ефективності господарської діяльності.

Пропонується, одним 3 основних напрямків розбудови потенціалу сільських територій використати реалізацію стратегічних планів сталого розвитку територій, які формуються відповідно до перспективних напрямів розвитку національної економіки. 3 метою покращення ситуації у галузі бджільництва, удосконалення соціально-економічних та організаційних умов для нарощування виробництва конкурентоспроможної продукції даної галузі, органами місцевого самоврядування на виконання вимог пункту 16 частини 1 статті 43 Закону України "Про місцеве самоврядування в Україні" здійснюється затвердження програм соціально-економічного розвитку відповідних територій, які мають цільовий характер. Бюджетне фінансування таких цільових програм $є$ однією 3 форм державної підтримки аграрного сектору. [2].

За необхідне, в умовах обмеженого фінансового ресурсу держави пропонується визначати чіткий та стислий перелік пріоритетів розвитку галузей економіки яким варто спрямовувати державну підтримку. Даний процес має визначатися, виходячи з реальних фінансових можливостей галузей економіки, здатних забезпечити сталий розвиток сільського господарства.

Водночас, бджільництво - одна 3 галузей, яка дозволяє збільшувати зайнятість населення і відкриття малого та середнього бізнесу на селі. А, зростання кількості приватних підприємців, фермерів, кооперативних та інших об'єднань в аграрному секторі, і як результат створення нових робочих місць зі зростанням доходів населення сільської території - це і є найкращий показник, що повністю відповідає цілям сталого розвитку.

При розробленні програми підтримки розвитку бджільництва у Волинській області, рекомендуємо встановити цільові показники розвитку галузі, зокрема:

цільовий показник чисельності бджолиних родин в області $-74,7$ тис родин.

цільовий показник середньої щільності бджолиних родин на 1 квадратний кілометр - 3,7 бджолородин.

цільовий показник середнього виробництва меду на одного жителя- 1,9 кілограм.

цільовий показник запилення медоносними бджолами основних ентомофільних сільськогосподарських культур - 34,2 відсотка.

цільовий показник кількісті суб'єктів підприємницької діяльності різних форм власності, в т.ч. сімейних фермерських господарств в галузі бджільництва -747 одиниць. 
Отримані матеріали, можуть бути взяті за основу при розробленні регіональних програм розвитку сектору АПК, та складанні бізнес-плану суб'єктами підприємницької діяльності різних форм власності при створенні пасік, та фермерських господарств в галузі сільського господарства, що в перспективі може послужити основою ефективного виробництва продукції рослинництва та бджільництва.

\section{Джерела та література}

1.Бородіна, О. М., 2015. Політика сільського розвитку на базі громад в Україні В: О.М. Бородіної І.В Прокопи, О.Л Попової, ред. Взаємопов'язаність сільського господарства і села як умова їх сталого розвитку. Київ: PERSE. с. 9-32.

2.Декларація Ріо-де-Жанейро щодо навколишнього середовища та розвитку: Декларація Організація Об'єднаних Націй від 14 червня 1992 p. 1992. [online] Доступно: https://zakon.rada.gov.ua/laws/show/995_455\#Text [Дата звернення 30 жовтня 2020]

3.Клименкова, Е., Кушнір, Л. та Бачило, А. 1980 Медоносы и медосбор, Мінськ: Ураджай

4.Поліщук В. 2001. Бджільництво Львів: Редакція журналу "Український пасічник"

5.Поліщук В., Гайдар, В. та Корбут, О. 2012. Пасека. Київ: Обнова

6.Пономарева, Є. 1967. Кормовая база пчеловодства и опылениесельскохозяйственныхрастений. Москва: Колос.

7.Про бджільництво: Закон України від 22 лютого 2000 p. № 1492-III 2000. [online] Доступно: https://zakon.rada.gov.ua/laws/show/1492-14\#Text [Дата звернення 25 жовтня 2020]

8.Про затвердження наборів продуктів харчування, наборів непродовольчих товарів та наборів послуг для основних соціальних і демографічних груп населення: Постанова Кабінету Міністрів України від 11 жовтня 2016 p. № 780 2016. [online] Доступно: https://zakon.rada.gov.ua/laws/show/780-2016-\%D0\%BF\#Теxt [Дата звернення 25 жовтня 2020]

9.Черкасова., А., Блонська, В. Та Губа, П. 1989. Бджільництво. Київ: Урожай.

10.Тваринництво України 2019: статистичний збірник, 2020. Київ Державна служба статистики України.

11."Сільське господарство Волині за 2019 рік статистичний збірник про соціально-економічний стан сільського господарства області та в районах за 2010, 2015-2019 роки", 2020, Луцьк Головне управління статистики у Волинській області.

12.Про Стратегію розвитку Волинської області на період до 2027 року: Рішення сесії Волинської обласної ради від 12 березня 2020 р. № 29/16 2020. [online] Доступно: http://volynrada.gov.ua/session/29/16-0 [Дата звернення 25 жовтня 2020]

13.Про затвердження галузевої Програми розвитку садівництва України на період до 2025 року і галузевої Програми розвитку виноградарства та виноробства України на період до 2025 року Наказ Міністерства Аграрної Політики України Українська Академія Аграрних Наук 21.07.2008 N 444/74

14.Сучасний стан та перспективи розвитку виробництва насіння сої в Україні Стрижак А.М. «Полтавська ДАА» Таврійський науковий вісник № 9

15.Урожайність рижію ярого і олійних культур в умовах західного лісостепу $A$. М. Лихочвор. Інститут сільського господарства Карпатського регіону НААН. Вісник Сумського національного аграрного університету.

16.Стан та проблеми функціонування підприємницьких структур в умовах перманентної економіки / Під ред. д.е.н., професора Ю.О. Нестерчук. - Умань: Видавець «Сочінський», 2016. - 263 с.

17.Метод агрометеорологічної оцінки і прогнозу врожайності соняшнику в Україні В.П.Дмитренко, Н.К.Строкач, Л.П.Однолєток Український науково - дослідний гідрометеорологічний інститут, Київ Наук. праці УкрНДГМІ, 2005, Вип. 254

18.Swinton M., Lupi F., Robertson P., Hamilton S. Ecosystemservicesandagriculture:Cultivatingagriculturalecosystemsfordiversebenefits // EcologicalEconomics.2007. No 64. P. 245-252.

19.О. В. Шкарупа, А. А. Треус, О. О. Часник. Економічні проблеми управління біоресурсами в Україні та Європейському Союзі „Механізм регулювання економіки”, 2017, № 4

20.Руттнер. Ф 2006. Техника разведения и селекционный отбор пчел: практическое руководство.7-ме вид. Москва: АСТАстрель.

21.Мішенін Є. В. Розвиток ринку екосистемних послуг як напрямок посткризового зростання економіки України. Є. В. Мішенін, Н. В. Олійник. - Механізми регулювання економіки. - 2010. - Т. 3, № 3. - С. 104-117.

22. Програма дій “Порядок денний на XXI століття" (“AGENDA 21”). - К. : Інтелсфера, 2000. - 360 с.].

23.Невесенко В. Д. Науково-методичні засади сталого розвитку сільського господарства. В. Д. Невесенко Наукові прачі Кіровоградського наџіонального технічного університету. Економічні науки. - 2011. - Вип. 19. C. 83-90. - Режим доступу: http://nbuv.gov.ua/UJRN/Npkntu_e_2011_19_15 
24. Філюк Д. О. Формування ефективності бджільництва в контексті соціально-економічного розвитку сільських територій. Перспективи розвитку бджільництва України. Матеріали науково-практичної конференції 3 міжнародною участю 16 серпня 2019 року м. Київ.

25. Шворак А., Філюк Д. Вплив синергетичного ефекту лісівництва і бджільництва на розвиток сільських територій Волинської області. Аграрна економіка 2020, Т. 13, № 3-4 Львів.

\section{References}

1. 1.Borodina, O.M., 2015. Polityka sil's'koho rozvytku na bazi hromad v Ukrayini V: O.M. Borodinoyi I.V Prokopy, O.L Popovoyi, red. Vzayemopov"yazanist' sil's'koho hospodarstva i sela yak umova yikh staloho rozvytku. Kyyiv: PERSE. s. 9-32. [In Ukrainian].

2. 2.Deklaratsiya Rio-de-Zhaneyro shchodo navkolyshn'oho seredovyshcha ta rozvytku: Deklaratsiya Orhanizatsiya Ob'yednanykh Natsiy vid 14 chervnya 1992 r. $1992 . \quad$ [online] Dostupno: https://zakon.rada.gov.ua/laws/show/995_455\#Text [Data zvernennya 30 zhovtnya 2020] [In Ukrainian].

3. 3.Klymenkova, E., Kushnir, L. ta Bachylo, A. 1980 Medonosy y medosbor, Mins'k: Uradzhay. [In Ukrainian].

4. 4.Polishchuk V. 2001. Bdzhil'nytstvo L'viv: Redaktsiya zhurnalu "Ukrayins'kyy pasichnyk"[In Ukrainian].

5.Polishchuk V., Haydar, V. ta Korbut, O. 2012. Paseka. Kyyiv: Obnova [In Ukrainian].

6.Ponomareva, YE. 1967. Kormovaya baza pchelovodstva y opylenyesel'skokhozyaystvennykhrastenyy. Moskva: Kolos. [In Ukrainian].

7.Pro bdzhil'nytstvo: Zakon Ukrayiny vid 22 lyutoho 2000 r. № 1492-III 2000. [online] Dostupno: https://zakon.rada.gov.ua/laws/show/1492-14\#Text [Data zvernennya 25 zhovtnya 2020]. [In Ukrainian].

8.Pro zatverdzhennya naboriv produktiv kharchuvannya, naboriv neprodovol'chykh tovariv ta naboriv posluh dlya osnovnykh sotsial'nykh i demohrafichnykh hrup naselennya: Postanova Kabinetu Ministriv Ukrayiny vid 11 zhovtnya 2016 r. № 780 2016. [online] Dostupno: https://zakon.rada.gov.ua/laws/show/780-2016-\%D0\%BF\#Text [Data zvernennya 25 zhovtnya 2020] [In Ukrainian].

9.Cherkasova., A., Blons'ka, V. Ta Huba, P. 1989. Bdzhil'nytstvo. Kyyiv: Urozhay. [In Ukrainian].

10.Tvarynnytstvo Ukrayiny 2019: statystychnyy zbirnyk, 2020. Kyyiv Derzhavna sluzhba statystyky Ukrayiny.

11."Sil's'ke hospodarstvo Volyni za 2019 rik statystychnyy zbirnyk pro sotsial'no-ekonomichnyy stan sil's'koho hospodarstva oblasti ta v rayonakh za 2010, 2015-2019 roky", 2020, Luts'k Holovne upravlinnya statystyky u Volyns'kiy oblasti. [In Ukrainian].

12.Pro Stratehiyu rozvytku Volyns'koyi oblasti na period do 2027 roku: Rishennya sesiyi Volyns'koyi oblasnoyi rady vid 12 bereznya 2020 r. № 29/16 2020. [online] Dostupno: http://volynrada.gov.ua/session/29/16-0 [Data zvernennya 25 zhovtnya 2020] [In Ukrainian].

13.Pro zatverdzhennya haluzevoyi Prohramy rozvytku sadivnytstva Ukrayiny na period do 2025 roku i haluzevoyi Prohramy rozvytku vynohradarstva ta vynorobstva Ukrayiny na period do 2025 roku Nakaz Ministerstva Ahrarnoyi Polityky Ukrayiny Ukrayins'ka Akademiya Ahrarnykh Nauk 21.07.2008 N 444/74. [In Ukrainian].

14.Suchasnyy stan ta perspektyvy rozvytku vyrobnytstva nasinnya soyi v Ukrayini Stryzhak A.M «Poltavs'ka DAA» Tavriys'kyy naukovyy visnyk № 9. [In Ukrainian].

15.Urozhaynist' ryzhiyu yaroho i oliynykh kul'tur v umovakh zakhidnoho lisostepu A. M. Lykhochvor, Instytut sil's'koho hospodarstva Karpat·s'koho rehionu NAAN Visnyk Sums'koho natsional'noho ahrarnoho universytetu. [In Ukrainian].

16.Stan ta problemy funktsionuvannya pidpryyemnyts'kykh struktur v umovakh permanentnoyi ekonomiky / Pid red. d.e.n., profesora YU.O. Nesterchuk. - Uman': Vydavets' «Sochins'kyy», 2016. - 263 s. [In Ukrainian].

17.Metod ahrometeorolohichnoyi otsinky i prohnozu vrozhaynosti sonyashnyku v Ukrayini V.P.Dmytrenko, N.K.Strokach, L.P.Odnolyetok Ukrayins'kyy naukovo - doslidnyy hidrometeorolohichnyy instytut, Kyyiv Nauk. pratsi UkrNDHMI, 2005, Vyp. 254. [In Ukrainian].

18.Swinton M., Lupi F., Robertson P., Hamilton S.(2017) Ecosystem services and agriculture: Cultivating agricultural ecosystems for diverse benefits. Ecological Economics. No 64. P. 245-252. [In Ukrainian].

19.O. V. Shkarupa, A. A. Treus, o. O. ChasnykEkonomichni problemy upravlinnya bioresursamyv Ukrayini ta Yevropeys'komu Soyuzi „Mekhanizm rehulyuvannya ekonomiky”, 2017, No 4. [In Ukrainian].

20.Ruttner. F 2006. Tekhnyka razvedenyya y selektsyonnyy otbo rpchel: praktycheskoe rukovodstvo.7-me vyd. Moskva: ASTAstrel'. [In Ukrainian].

21.Mishenin YE. V. (2010) Rozvytok rynku ekosystemnykh posluh yak napryamok postkryzovoho zrostannya ekonomiky Ukrayiny. YE. V. Mishenin, N. V. Oliynyk. Mekhanizmy rehulyuvannya ekonomiky. 2010. T. 3, № 3. S. 104-117. [In Ukrainian].

22. Prohrama diy "Poryadok dennyy na KHKHI stolittya" (“AGENDA 21"). K. : Intelsfera, 2000. 360 s. [In Ukrainian]. 
23. Nevesenko V. D. 2011. Naukovo-metodychni zasady staloho rozvytku sil's'koho hospodarstva. V. D. Nevesenko. Naukovi pratsi Kirovohrads'koho natsional'noho tekhnichnoho universytetu. Ekonomichni nauky. 2011. Vyp. 19. - S. 83-90. - Rezhym dostupu: http://nbuv.gov.ua/UJRN/Npkntu_e_2011_19_15. [In Ukrainian].

24. Filyuk D. O. Formuvannya efektyvnosti bdzhil'nytstva $v$ konteksti sotsial'no-ekonomichnoho rozvytku sil's'kykh terytoriy // Perspektyvy rozvytku bdzhil'nytstva Ukrayiny. Materialy naukovo-praktychnoyi konferentsiyi z mizhnarodnoyu uchastyu 16 serpnya 2019 roku m. Kyyiv. [In Ukrainian].

25. Shvorak A., Filyuk D. (2020) Vplyv synerhetychnoho efektu lisivnytstva i bdzhil'nytstva na rozvytok sil's'kykh terytoriy Volyns'koyi oblasti. Ahrarna Ekonomika, T. 13, № 3-4 L'viv.. [In Ukrainian].

Стаття надійшла до редакції 18.02.2021 р. 